\title{
Pengintegrasian Pendidikan Nilai-Nilai Budaya Dan Karakter Bangsa Dalam Pembelajaran Matematika Pada Pokok Bahasan Aljabar Dan Aritmetika Sosial Di SMP Negeri 1 Kabupaten Sorong
}

\author{
Sinutomo \\ SMP Negeri 1 Kabupaten Sorong \\ Email: sinutomo@ymail.com
}

\begin{abstract}
This research was a Classroom Action Research (CAR) which was aimed at finding out whether the integration of cultural values education and national characters in Mathematics learning could improve the students' characters and also improve the students' ability to be independent, creative and nationalinsighted students. The subject of this research was 30 students of Class VII G of SMP Negeri 1 Sorong Regency. This research was conducted by using test and non-test techniques and analyzing teacher's teaching activities and students' learning result. This research was done into two cycles which every cycle consists of planning, action, observation and reflection. The data was obtained from teacher's and students' activities which were collected through the observation sheets, and the data of students' learning result were collected through the test given at the end of every cycle. The result of the research showed the improvement of students' characters scores from the Cycle I to the Cycle II. It could be seen from the percentage of students in developing stages that increased in every meeting, they were $28 \%, 36 \%, 56 \%$ and $72 \%$. The students' achievement also increased at the first test until the test of Cycle II, they were $28 \%, 64 \%$ and $76 \%$. From the data given above, it could be inferred that the integration of cultural values education and national characters in Mathematics learning could improve the students' characters and also improve the students' ability to be independent, creative and national-insighted students.
\end{abstract}

Keywords: integration, characters education, Mathematic learning

Abstrak: Penelitian ini merupakan penelitian tindakan kelas yang bertujuan untuk mengetahui apakah dengan pengintegrasian pendidikan nilai-nilai budaya dan karakter bangsa dalam pembelajaran matematika dapat meningkatkan karakter siswa, serta meningkatkan kemampuan siswa menjadi manusia yang mandiri, kreatif, dan berwawasan kebangsaan. Subjek penelitian adalah siswa kelas VII G SMP Negeri 1 Kabupaten Sorong sebanyak 30 orang. Teknik penelitian yang digunakan adalah teknik tes dan non-tes dengan menganalisis aktivitas mengajar guru dan hasil belajar siswa. Penelitian ini dilakukan dalam dua siklus, pada setiap siklus dilakukan kegiatan yang berkaitan yaitu perencanaan, tindakan, pengamatan dan refleksi. Data dalam penelitian ini diperoleh dari data aktivitas guru dan siswa yang dikumpulkan melalui lembar observasi, serta data tentang hasil belajar siswa dikumpulkan melalui pemberian tes pada setiap akhir siklus. Hasil penelitian ini menunjukkan bahwa perkembangan nilai karakter siswa meningkat dari siklus I ke siklus II. Hal ini dilihat dari persentase siswa yang berada pada tahapan perkembangan mulai berkembang meningkat pada setiap pertemuan, yaitu 28\%, 36\%, 56\% dan $72 \%$. Terjadi peningkatan prestasi siswa, pada tes awal sampai tes siklus dua yaitu: $28 \%, 64 \%, 76 \%$. Dengan demikian, disimpulkan bahwa pengintegrasian pendidikan nilai-nilai budaya dan karakter bangsa dalam pembelajaran matematika dapat meningkatkan nilai karakter siswa serta meningkatkan kemampuan siswa menjadi manusia yang mandiri, kreatif dan berwawasan kebangsaan.

Kata kunci: pengintegrasian, pendidikan karakter, pembelajaran matematika

\section{Pendahuluan}

Berdasarkan informasi awal yang diperoleh dari guru mata pelajaran matematika di SMP Negeri 1 Kabupaten Sorong diketahui bahwa hasil belajar matematika siswa belum memuaskan. Hal ini dapat dilihat dari hasil Ujian Nasional matematika secara umum dan masih banyak siswasiswi yang mengalami kesulitan dalam mata pelajaran matematika. Siswa-siswi sering mengeluh 
tidak bisa memahami konsep-konsep matematika yang diberikan oleh guru sehingga siswa-siswi ini sering tidak memenuhi Kriteria Ketuntasan Minimal (KKM) di sekolah tersebut. Salah satu materi yang dianggap sulit dan membutuhkan analisis serta kemampuan berpikir yang lebih kreatif bagi para siswa SMP yaitu materi Aljabar dan Aritmetika Sosial di kelas VII G. Terdapat sejumlah siswa yang setelah mempelajari sub pokok bahasan tersebut sering mengeluh karena tidak memahami konsep-konsep yang diajarkan oleh guru. Siswa juga mengalami kesulitan dalam melakukan operasi-operasi hitung jika diberikan dalam bentuk aljabar. Serta dalam pemecahkan masalah aritmetika sosial sederhana, siswa kesulitan untuk mengunakan konsep-konsep aljabar. Alasan-alasan di atas dipertegas oleh persentasi standar kompetensi lulusan (SKL) khusus materi Aljabar dan Aritmetika Sosial yang masih rendah. Pada proses pembelajarannya pun, siswa hanya difokuskan pada materi yang diajarkan, dan nilai karakter utama dalam matematika (Berpikir Logis-Kritis-Kreatif-Inovatif, Kerja Keras, Keingintahuan, Kemandirian, dan Percaya Diri) belum dikembangkan secara optimal. Hal ini dilihat ketika siswa mengalami kesulitan dalam proses pembelajaran, siswa pada umumnya malu dan takut untuk bertanya kepada guru terutama siswa yang berkemampuan rendah. Mereka cenderung diam dan enggan dalam mengemukakan pertanyaan atau pendapat. Serta Kemandirian siswa dalam belajar matematika belum nampak dan banyak ditemukan siswa pada awal pembelajaran kadang tidak mengetahui apa yang akan dipelajari, ia hanya bergantung pada gurunya. Di lain pihak umumnya jumlah siswa pada suatu kelas terlalu besar, kurangnya alat pelajaran dan siswa perlu mendapat kesempatan untuk bekerja dalam kelompok, serta memperoleh umpan balik padahal waktu guru terbatas. Hal ini mengakibatkan Pelajaran Matematika sebagai dasar dari ilmu-ilmu yang lain belum sepenuhnya berhasil menjalankan tujuannya yaitu untuk mendidik siswa menjadi manusia yang dapat berfikir logis, kritis dan rasional serta menduduki peranan penting dalam dunia pendidikan. Bertolak dari uraian di atas, penulis tertarik melakukan penelitian untuk meningkatkan nilai karakter siswa melalui pembelajaran matematika dengan judul penelitian : "Pengintegrasian Pendidikan NilaiNilai Budaya Dan Karakter Bangsa Dalam Pembelajaran Matematika Pokok Bahasan Aljabar Dan Aritmetika Sosial Di SMP Negeri 1 Kabupaten Sorong”.

Pengintegrasian pendidikan nilai-nilai budaya dan karakter bangsa dalam pembelajaran matematika yaitu dengan mengenalkan nilai-nilai karakter kepada siswa melalui proses pembelajaran baik yang berlangsung didalam maupun diluar kelas pada mata pelajaran matematika. sehingga, kegiatan pembelajaran, selain menjadikan siswa menguasai materi yang diberikan, juga siswa dapat mengenal, menyadari, menginternalisasi nilai-nilai budaya dan karakter, dan menjadikannya perilaku. Nilai karakter yang ditanamkan pada siswa melalui mata pelajaran matematika di SMP adalah nilai karakter utama mata pelajaran matematika karena paling dekat dengan karakteristik mata pelajaran matematika di SMP, yang terdiri atas Berpikir LogisKritis-Kreatif-Inovatif, Kerja Keras, Keingintahuan, Kemandirian, dan Percaya Diri. Integrasi 
pendidikan karakter didalam proses pembelajaran dilaksanakan mulai dari tahap perencanaan, pelaksanaan, dan evaluasi pembelajaran.

\section{Metode Penelitian}

\subsection{Desain Penelitian}

Penelitian ini merupakan Penelitian Tindakan Kelas (Classroom Action Research), yang pada setiap siklusnya terdiri atas empat tahap, yaitu 1) perencanaan, 2) tindakan, 3) pengamatan, dan 4) refleksi.

\subsection{Subjek Penelitian}

Subjek penelitian adalah siswa kelas VII G SMP Negeri 1 Kabupaten Sorong semester 2 tahun pelajaran 2015/2016 sebanyak 30 siswa. Faktor yang diteliti dalam penelitian tindakan kelas ini adalah faktor guru, ketuntasan belajar siswa dan aktivitas siswa dalam proses pembelajaran.

\subsection{Prosedur Penelitian}

Prosedur penelitian dilakukan dengan beberapa siklus yaitu sebagai berikut.

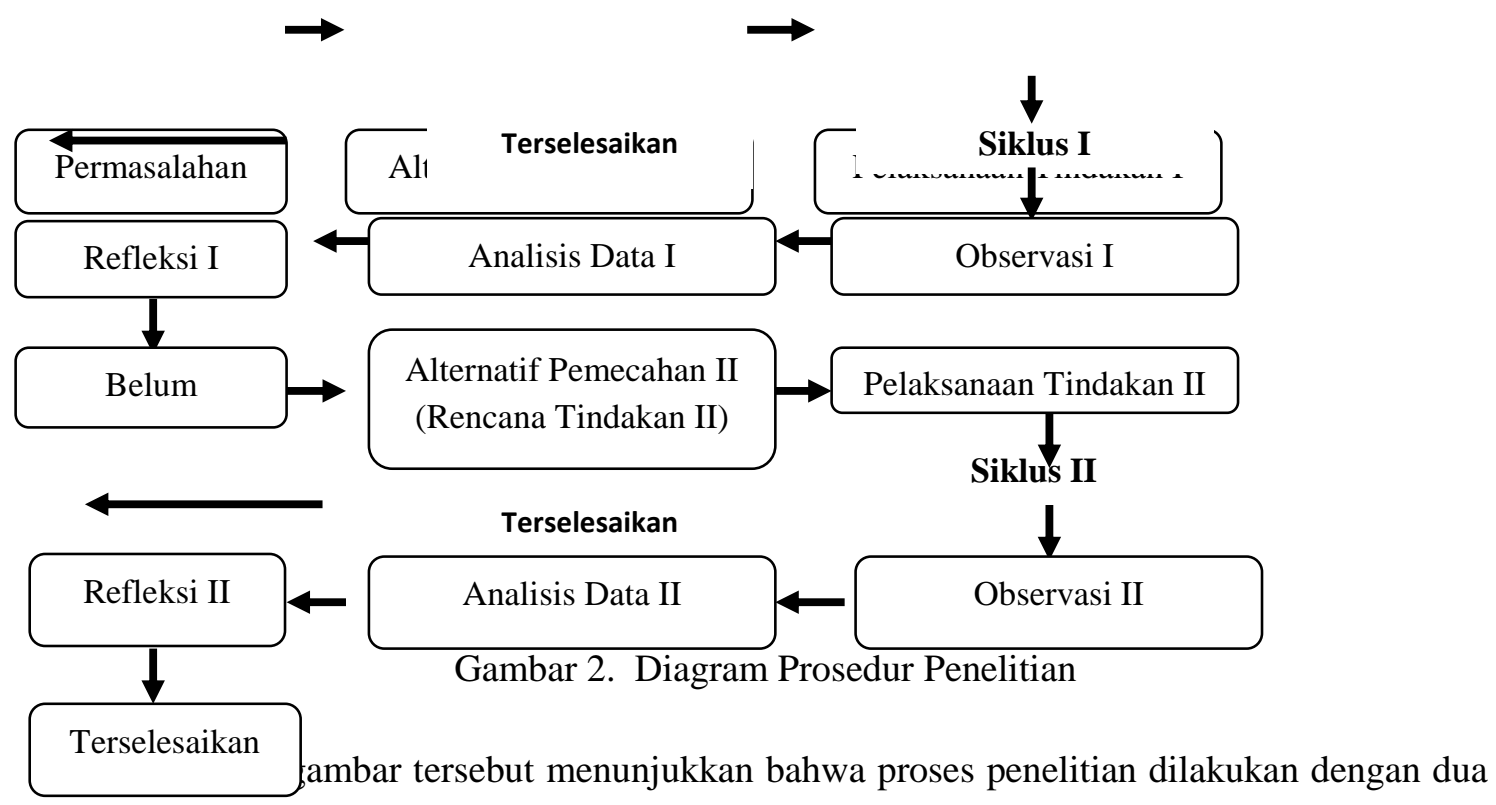

siklus yang memuat aspek perencanaan, tindakan, observasi dan refleksi.

\section{Hasil Penelitian dan Pembahasan}

Pada bagian ini juga akan dibahas hasil penelitian yang dilakukan dimana setelah pengumpulan data, pengolahan data dan analisis data maka dapat dilihat bahwa pengintegrasian pendidikan karakter dalam pembelajaran dapat meningkatkan hasil belajar siswa dalam pembelajaran matematika dan juga dapat meningkatkan nilai karakter siswa. Hal ini dibuktikan dengan kemampuan siswa dalam memahami materi, menjawab soal-soal dengan tepat dan benar, serta keaktifan siswa dalam belajar dan mengeluarkan ide dalam pembelajaran semakin 
meningkat. Berikut beberapa kesimpulan yang dapat diambil dari hasil penelitian adalah sebagai berikut:

$>$ Hasil observasi kemampuan guru dalam mengelola pembelajaran. Hasil observasi kemampuan guru dalam megelola pembelajaran adalah untuk siklus I mencapai skor 4,2 dan untuk siklus II meningkat mencapai skor 4,9 yang berada pada kategori membudaya. Hasil di atas menunjukan bahwa kemampuan guru dalam mengelola pembelajaran mengalami peningkatan.

> Hasil observasi aktivitas siswa dalam mengelola pembelajaran. Hasil observasi aktivitas siswa dalam pembelajaran untuk siklus I yang berada pada tahapan mulai berkembang sebanyak $28 \%$ atau 7 orang, dan untuk siklus II meningkat menjadi $72 \%$ atau 18 orang. Hasil tersebut menunjukkan bahwa aktivitas siswa dalam pembelajaran matematika khususnya untuk materi aljabar dan aritmetika sosial dengan pengintegrasian pendidikan nilai budaya dan karakter bangsa mengalami peningkatan.

> Hasil analisis tes setiap siklus Hasil tes setiap siklus yang dianalisis adalah ketuntasan belajar siswa secara individu maupun secara klasikal. Berdasarkan standar ketuntasan belajar siswa peneliti menganalisis hasil belajar siswa secara individu sebagaimana ditunjukkan dalam lampiran, dan hasil analisis ketuntasan belajar siswa secara klasikal adalah untuk siklus I sebanyak 16 siswa atau 64\% dengan kategori tuntas dan 9 siswa atau $36 \%$ dengan kategori belum tuntas, untuk siklus II sebanyak 19 orang atau $76 \%$ dengan kategori tuntas sedangkan 6 siswa atau 24\% dengan kategori belum tuntas.

Tanggapan tentang pelaksanaan penelitian tindakan kelas Pelaksanaan tindakan kelas ini ditanggapi baik oleh bapak dan ibu guru serta siswa-siswi di sekolah tersebut. Selain memberi kesan yang positif, dengan adanya penelitian tindakan kelas ini dapat memotivasi para guru di sekolah tersebut untuk melaksanakan pembelajaran yang berasaskan pendidikan budaya dan karakter bangsa, serta membantu siswa untuk mengembangkan nilai karakter yang sudah dimiliki. Hal ini tercermin dari keantusiasan guru dan siswa dalam mengikuti proses belajar mengajar yang diintegrasikan dengan pendidikan budaya dan karakter bangsa. Dan juga pelaksanaan tindakan kelas ini sangat bermanfaat bagi siswa karena dalam penyajian materi kepada siswa selalu dikombinasikan dengan masalah matematika sehari-hari dan masalah matematika yang tidak umum, yang pada pemecahannya membutuhkan kreativitas yang tinggi dari siswa.

\section{Kesimpulan dan Saran}

\subsection{Kesimpulan}

Berdasarkan hasil penelitian yang telah dilakukan, maka dapat disimpulkan bahwa: 
1. Pengintegrasian pendidikan nilai-nilai budaya dan karakter bangsa dalam pembelajaran matematika pada siswa kelas VII G SMP Negeri 1 Kabupaten Sorong pada pokok bahasan aljabar dan aritmetika sosial dapat meningkatkan karakter siswa, hal ini dapat dilihat dari persentase peningkatan nilai karakter siswa untuk setiap siklus yaitu Siklus I sebanyak 14 orang atau 56\% yang mulai berkembang, dan Siklus II sebanyak 18 orang atau $72 \%$ yang mulai berkembang.

2. Pengintegrasian pendidikan nilai-nilai budaya dan karakter bangsa dalam pembelajaran matematika pada siswa kelas VII G SMP Negeri 1 Kabupaten Sorong pada pokok bahasan aljabar dan aritmetika sosial dapat meningkatkan kemampuan siswa menjadi manusia yang mandiri, kreatif, dan berwawasan kebangsaan, yaitu meningkat sebesar 12\% dari 64\% pada Siklus I menjadi $76 \%$ pada Siklus II.

3. Kendala yang dihadapi adalah kurang terbiasanya guru memberikan soal-soal yang berkaitan dengan masalah matematika dalam kehidupan sehari-hari sehingga siswa agak kesulitan.

\subsection{Saran}

Berdasarkan dengan kesimpulan di atas, peneliti menyarankan sebagai berikut :

1. Kepada guru matematika untuk mengintegrasikan pendidikan nilai-nilai budaya dan karakter bangsa dalam pembelajaran matematika pada pokok bahasan lainnya, misalnya bilangan bulat, persamaan linear dan lain-lain.

2. Kepada guru mata pelajaran lain untuk mengintegrasikan pendidikan nilai-nilai budaya dan karakter bangsa dalam proses pembelajaran.

3. Kepada guru matematika untuk selalu membiasakan siswa untuk menyelesaikan masalah matematika dalam kehidupan sehari-hari.

4. Guru matematika hendaknya menggunakan model pembelajaran yang bervariasi sesuai dengan materi yang akan disampaikan sehingga tidak membosankan bagi siswa.

5. Kepada penelitian selanjutnya disarankan agar dalam pengintegrasian pendidikan nilai budaya dan karakter bangsa dalam pembelajaran matematika tidak hanya terbatas pada nilai karakter utama matematika saja, tetapi diintegrasikan juga dengan nilai-nilai karakter yang lain.

\section{Daftar Pustaka}

Badan Penelitian dan Pengembangan Pusat Kurikulum. 2010. Pengembangan Pendidikan Budaya dan Karakter Bangsa. Jakarta. Kemdiknas

Direktorat Pembinaan SMP. 2010. Pendidikan Karakter di Sekolah Menengah Pertama. Jakarta: Kemdiknas.

Kesuma, Dharma, dkk. 2011.Pendidikan Karakter Kajian Teori dan Praktik di Sekolah. Bandung. Remaja Rosdakarya

Nuharini, Dewi. 2008.Matematika Konsep dan Aplikasinya untuk SMP / MTs kelas VII. Jakarta. Depdiknas 
Raka, Gede, dkk .2011. Pendidikan Karakter di Sekolah Dari Gagasan Ke Tindakan. Jakarta. Media Komputindo

Rosida. 2009. Penunjang Belajar Matematika Untuk SMP/MTs Kelas VII . Jakarta : Depdiknas

Slameto. 2003. Belajar dan Faktor-faktor yang mempengaruhinya. Jakarta: Rineka Cipta.

W.J.S. Poerwodarminto. 1996. Kamus Besar Bahasa Indonesia. Jakarta: Balai Pustaka

Wintarti, Atik, dkk. 2008. Contextual Teaching and Learning Matematika: Sekolah Menengah Pertama Kelas VII . Jakarta: Depdiknas Manik,

Zuchdi, Darmiyati, dkk. 2010. Pendidikan karakter dengan pendekatan komperhensif. Jogjakarta. UNY Pres 